\title{
Irrigation Requirements for Seed Production of Five Lomatium Species in a Semiarid Environment
}

\author{
Clinton C. Shock ${ }^{1,7}$, Erik B.G. Feibert ${ }^{2}$, Alicia Rivera ${ }^{3}$, \\ and Lamont D. Saunders ${ }^{4}$ \\ Malheur Experiment Station, Oregon State University, 595 Onion Avenue, \\ Ontario, OR 97914 \\ Nancy Shaw ${ }^{5}$ and Francis F. Kilkenny ${ }^{6}$ \\ U.S. Forest Service, Rocky Mountain Research Station, 322 E. Front Street, \\ Suite 401, Boise, ID 83702
}

Additional index words. subsurface drip irrigation, medicinal plant, rangeland restoration

\begin{abstract}
Seeds of native plants are needed for rangeland restoration in the Intermountain West. Many of these plants are rarely cultivated and relatively little is known about the cultural practices required for their seed production. Irrigation trials were conducted for five perennial Lomatium species over multiple years. Lomatium species grown at the Oregon State University Malheur Experiment Station, Ontario, OR received 0, 100, or $200 \mathbf{~ m m}$ of irrigation per year. Seed yield responses to irrigation were evaluated by linear and quadratic regression. In general, seed yields from the three species grown for 10 years responded linearly or quadratically to irrigation. To improve the accuracy of estimated irrigation water requirements, regressions were also run on seed yield responses to irrigation plus precipitation during the previous spring; spring and winter; and spring, winter, and fall. Over multiple years, Lomatium dissectum (Nutt.) Mathias \& Constance and $L$. triternatum (Pursh) J.M. Coult. \& Rose seed yields were best estimated by a quadratic response to irrigation plus spring precipitation with highest yields at 243 and $255 \mathrm{~mm}$, respectively. Lomatium grayi (J.M. Coult. \& Rose) J.M. Coult. \& Rose seed yields were best estimated by a quadratic response to irrigation plus precipitation during the fall, winter, and spring with highest yields at $358 \mathrm{~mm}$. Two of the Lomatium species were grown for the last 6 years. The seed yields of $L$. nudicaule (Pursh) J.M. Coult. \& Rose did not respond to irrigation. Seed yields of Lomatium suksdorfii (S. Watson) J.M. Coult. \& Rose responded linearly to irrigation in 2015.
\end{abstract}

Seeds of native plants are needed for rangeland restoration in the Intermountain West due to increasing rates of disturbance caused by non-native plant invasions and more frequent wildfires (Balch et al., 2013; Liu and Wimberly, 2015). Postfire restoration can stabilize soils and reduce re-establishment of invasive annuals, although restoration effectiveness depends on techniques and seed mixes (Robichaud et al., 2000). A recent synthesis showed that restoration of forbs

Received for publication 11 July 2016. Accepted for publication 2 Aug. 2016.

This project was partially funded by the USDA Forest Service, Rocky Mountain Research Station's Great Basin Native Plant Project, USDI Bureau of Land Management, Oregon State University, Malheur County Education Service District, and by formula grants 2015-31100-06041 and 2015-31200-06041 from the USDA National Institute of Food and Agriculture.

${ }^{1}$ Professor and Director.

${ }^{2}$ Senior Faculty Research Assistant.

${ }^{3}$ Bioscience Research Technician I.

${ }^{4}$ Bioscience Research Technician III.

${ }^{5}$ Research Botanist (Emeritus).

${ }^{6}$ Research Biologist.

${ }^{7}$ Corresponding author. E-mail: clinton.shock@ oregonstate.edu.
Many Lomatium species were used by Native Americans for their food and medicinal properties (Shock et al., 2012a, 2012b; Tilley et al., 2010a, 2010b), and evaluation and use of such species as L. suksdorfii (Suksdorf's desertparsley) continue today (Lee et al., 1994). Except for L. suksdorfii, which is found only in south-central Washington and north-central Oregon, these species are widespread in the Intermountain West. Lomatium species grow in scattered to occasionally dense stands on well-drained coarseto fine-textured soils and on scablands, rocky slopes, drainages, and open ridges.

Large-statured and widely distributed Lomatiums are valued as restoration species because they are among the earliest wildflowers to green up in late winter or spring. They provide a source of forage for wildlife (elk, deer, and antelope) and domestic livestock (sheep and cattle) (Ogle and Brazee, 2009). Barnett and Crawford (1994) reported that sage-grouse hens ate Lomatium leaves and stems, while Drut et al. (1994) found that sage-grouse chicks also consumed Lomatium. The Lomatium species were not identified in either study. Lomatiums are also used by birds, small mammals, pollinators, and other insects (Thompson, 1998). Lomatium species compete with non-native annuals such as Bromus tectorum (cheatgrass) because of their early spring growth and deep taproot system (Parkinson et al., 2013; Tilley et al., 2010a, 2010b).

Commercial seed production of Lomatium is needed for use in rangeland restoration plantings in the Intermountain West, but these plants are rarely cultivated, and cultural practices for seed production are largely unknown. A major limitation to economically viable commercial production of Lomatium seed is achieving stable and consistent seed production from year to year. In native rangelands, natural variation in spring rainfall and soil moisture results in highly unpredictable water stress at flowering, seed set, and seed development, which for many seed crops is known to compromise seed yield and quality. The seed yield response of $L$. dissectum to irrigation has been reported previously without considering the effect of precipitation (Shock et al., 2012b, 2015).

Native forbs are not well adapted to row crop production practices. Supplemental water can be provided by sprinkler or furrow irrigation systems, but these irrigation systems risk encouraging weeds and fungal pathogens. Subsurface drip irrigation can reduce wetting of the soil surface and could reduce weed and disease pressure.

The trials reported here tested the effects of three low rates of subsurface drip irrigation on the seed yield of five Lomatium species. The optimum amount of irrigation for each species was evaluated based not only on the amount of irrigation but also on the amount of seasonal precipitation each year.

\section{Methods} The leaves dieback after seed set, usually in midsummer. Lomatium species are dormant from late summer through winter and do not resume growth with fall rains.
An irrigation trial for $L$. dissectum, $L$. grayi, and L. triternatum was initiated in 
Table 1. Lomatium species planted in drip irrigation trials at the Malheur Experiment Station, Oregon State University, Ontario, OR.

\begin{tabular}{|c|c|c|}
\hline Species & Common names & Location of seed collection \\
\hline Lomatium grayi & Gray's biscuitroot, Gray's lomatium & Weiser River Road, ID (lat. $44.260^{\circ} \mathrm{N}$, long. $116.770^{\circ} \mathrm{W}$ ) \\
\hline Lomatium nudicaule & Barestem biscuitroot, barestem lomatium & Elko County, NV (lat. $41.119^{\circ} \mathrm{N}$, long. $116.510^{\circ} \mathrm{W}$ ) \\
\hline
\end{tabular}

2005 at the Malheur Experiment Station of Oregon State University, Ontario, OR. Ontario is centered at $43^{\circ} 58^{\prime} 42.2^{\prime \prime} \mathrm{N}, 117^{\circ} 1^{\prime} 29.8^{\prime \prime}$ at $689 \mathrm{~m}$ elevation. Annual precipitation averages $257 \mathrm{~mm}$. The field, a Nyssa silt loam (coarse-silty, mixed, mesic, Xeric Haplodurid), was bedded into $76-\mathrm{cm}$ rows, four rows per bed. Most of the field lacked topsoil due to land leveling in the 1950s. The analysis of a soil sample taken on 22 Nov. 2005 indicated a $\mathrm{pH}$ of $8.3,1.09 \%$ organic matter, $12 \mathrm{ppm}$ phosphorus $(\mathrm{P}), 438 \mathrm{ppm}$ potassium, $27 \mathrm{ppm}$ $\mathrm{SO}_{4}$-sulfur, $4370 \mathrm{ppm}$ calcium, $456 \mathrm{ppm}$ magnesium, $81 \mathrm{ppm}$ sodium, $1.6 \mathrm{ppm}$ zinc $(\mathrm{Zn})$, $0.6 \mathrm{ppm}$ copper, $4 \mathrm{ppm}$ manganese, $3 \mathrm{ppm}$ iron (Fe), and $0.6 \mathrm{ppm}$ boron.

Drip tape (T-Tape TSX 515-16-340; T Systems International Inc., San Diego, CA) was buried at $30-\mathrm{cm}$ depth and spaced $1.52 \mathrm{~m}$ apart beneath alternating inter-row spaces. The flow rate for the drip tape was $4.16 \mathrm{~L} / \mathrm{min}$ / $100 \mathrm{~m}$ at $55 \mathrm{kPa}$ with emitters spaced $41 \mathrm{~cm}$ apart, resulting in a water application rate of $1.7 \mathrm{~mm} \cdot \mathrm{h}^{-1}$. Water was filtered through sand media filters. Application durations were controlled automatically.

Seed of $L$. dissectum, $L$. grayi, and $L$. triternatum was planted on 26 Oct. 2005 in four rows $133 \mathrm{~m}$ long spaced $76 \mathrm{~cm}$ apart using a custom-made small-plot grain drill with disk openers. Seed was planted at $12.5-\mathrm{mm}$ depth with $65-100$ seeds/m of row. Seed of each species came from wild collections made by U.S. Forest Service employees (Table 1).

On 25 Nov. 2009, seed of L. nudicaule and L. suksdorfii was planted in the same field as the other Lomatium species in four rows spaced $76 \mathrm{~cm}$ apart using the small-plot grain drill. All seed was planted on the soil surface with 65-100 seeds/m of row. After planting, sawdust was applied in a narrow band over the seed row at $26 \mathrm{~g} \cdot \mathrm{m}^{-1}$ of row, and the beds were covered with rowcover. Each rowcover (N-sulate Deluxe Plus 1 oz; DeWitt Co., Inc., Sikeston, MO) covered two rows and was applied with a mechanical plastic mulch layer. The field was irrigated for $24 \mathrm{~h}$ on 2 Dec. 2009 due to very dry soil conditions.

In April following fall planting, each Lomatium strip was divided into twelve 9.1-mlong plots. Each plot contained four rows spaced $76 \mathrm{~cm}$ apart. The experimental design was a randomized complete block with four replicates.

The three irrigation treatments were 0 (control), 100 , and $200 \mathrm{~mm} /$ year. The $100-\mathrm{mm}$ and 200-mm irrigation treatments received four irrigations, 2 weeks apart, starting at the beginning of flowering. Each irrigation applied 25 (100-mm treatment) or $50 \mathrm{~mm}(200-\mathrm{mm}$ treatment) of water. In 2007 , irrigation treatments were inadvertently continued after the

Table 2. Lomatium flowering, irrigation, and seed harvest dates by species, 2006-15.

\begin{tabular}{|c|c|c|c|c|c|c|c|}
\hline \multirow[b]{2}{*}{ Species } & \multirow[b]{2}{*}{ Yr } & \multicolumn{3}{|c|}{ Flowering } & \multicolumn{2}{|c|}{ Irrigation } & \multirow[b]{2}{*}{ Harvest } \\
\hline & & Start & Peak & End & Start & End & \\
\hline \multirow[t]{10}{*}{ Lomatium dissectum } & 2006 & & & & 19 May & 30 June & \\
\hline & 2007 & & & & 5 Apr. & 24 June & \\
\hline & 2008 & & & & 10 Apr. & 29 May & \\
\hline & 2009 & 10 Apr. & & 7 May & 20 Apr. & 28 May & 16 June \\
\hline & 2010 & 25 Apr. & & 20 May & 15 Apr. & 28 May & 21 June \\
\hline & 2011 & 8 Apr. & 25 Apr. & 10 May & 21 Apr. & 7 June & 20 June \\
\hline & 2012 & 9 Apr. & 16 Apr. & 16 May & 13 Apr. & 24 May & 4 June \\
\hline & 2013 & 10 Apr. & & 25 Apr. & 4 Apr. & 16 May & 4 June \\
\hline & 2014 & 28 Mar. & & 21 Apr. & 7 Apr. & 20 May & 2 June \\
\hline & 2015 & 1 Apr. & & 24 Apr. & 1 Apr. & 13 May & 26 May and 1 June \\
\hline \multirow{10}{*}{ Lomatium grayi } & 2006 & & & & 19 Мау & 30 June & \\
\hline & 2007 & 5 Apr. & & 10 May & 5 Apr. & 24 June & 30 May and 29 June \\
\hline & 2008 & 25 Mar. & & 15 May & $10 \mathrm{Apr}$. & 29 May & 30 May and 19 June \\
\hline & 2009 & 10 Mar. & & 7 May & 20 Apr. & 28 May & 16 June \\
\hline & 2010 & 15 Mar. & & 15 May & 15 Apr. & 28 May & 22 June \\
\hline & 2011 & 1 Apr. & 25 Apr. & 13 May & 21 Apr. & 7 June & 22 June \\
\hline & 2012 & 15 Mar. & 25 Apr. & 16 May & 13 Apr. & 24 May & 14 June \\
\hline & 2013 & 15 Mar. & & 30 Apr. & 4 Apr. & 16 May & 10 June \\
\hline & 2014 & 28 Mar. & & 2 May & 7 Apr. & 20 May & 10 June \\
\hline & 2015 & 1 Mar. & & 28 Apr. & 1 Apr. & 13 May & 1 June \\
\hline \multirow[t]{10}{*}{ Lomatium triternatum } & 2006 & & & & 19 May & 30 June & \\
\hline & 2007 & 25 Apr. & & 1 June & 5 Apr. & 24 June & 29 June and 16 July \\
\hline & 2008 & 25 Apr. & & 5 June & 10 Apr. & 29 May & 3 July \\
\hline & 2009 & 10 Apr. & 7 May & 1 June & 20 Apr. & 28 May & 26 June \\
\hline & 2010 & 25 Apr. & & 15 June & 15 Apr. & 28 May & 22 July \\
\hline & 2011 & 30 Apr. & 23 May & 15 June & 21 Apr. & 7 June & 26 July \\
\hline & 2012 & 12 Apr. & 17 May & 6 June & 13 Apr. & 24 May & 21 June \\
\hline & 2013 & 18 Apr. & & 10 May & 4 Apr. & 16 May & 4 June \\
\hline & 2014 & 7 Apr. & 29 Apr. & 2 May & 7 Apr. & 20 May & 4 June \\
\hline & 2015 & 10 Apr. & 28 Apr. & 20 May & 1 Apr. & 13 May & 7 and 15 June \\
\hline \multirow[t]{5}{*}{ Lomatium nudicaule } & 2011 & & o floweri & & & & \\
\hline & 2012 & 12 Apr. & 1 May & 30 May & 18 Apr. & 30 May & 22 June \\
\hline & 2013 & 11 Apr. & & 20 May & 12 Apr. & 22 May & 10 June \\
\hline & 2014 & 7 Apr. & & 13 May & 7 Apr. & 20 May & 16 June \\
\hline & 2015 & 25 Mar. & & 5 May & 1 Apr. & 13 May & 8 June \\
\hline \multirow[t]{3}{*}{ Lomatium suksdorfii } & 2013 & 18 Apr. & & 23 May & & & \\
\hline & 2014 & 15 Apr. & & 20 May & 7 Apr. & 20 May & 30 June \\
\hline & 2015 & 3 Apr. & 27 Apr. & 10 May & 1 Apr. & 13 May & 23 June \\
\hline
\end{tabular}

fourth irrigation following seed production, doubling the planned irrigation amounts for each treatment. Flowering dates for each species were recorded and are reported in conjunction with the irrigation dates in Table 2.

Fertilization of the irrigation trial over the 6 years was minimal. On 11 Nov. 2006, nitrogen (N) at $112 \mathrm{~kg} \cdot \mathrm{ha}^{-1}$ as urea was broadcast. The following nutrients were applied as soluble nutrients through the drip irrigation: 27 Oct. 2006: $\mathrm{P}$ at $56 \mathrm{~kg} \cdot \mathrm{ha}^{-1}$ and $\mathrm{Zn}$ at $2.2 \mathrm{~kg} \cdot \mathrm{ha}^{-1} ; 9$ Apr. 2009: $\mathrm{N}$ at $56 \mathrm{~kg} \cdot \mathrm{ha}^{-1}$ and $\mathrm{P}$ at $11 \mathrm{~kg} \cdot \mathrm{ha}^{-1}$; 3 May 2011: N at $56 \mathrm{~kg} \cdot \mathrm{ha}^{-1}$; 13 Apr. 2012: N at $56 \mathrm{~kg} \cdot \mathrm{ha}^{-1}, \mathrm{P}$ at $11 \mathrm{~kg} \cdot \mathrm{ha}^{-1}$, and $\mathrm{Fe}$ at 0.012 $\mathrm{kg} \cdot \mathrm{ha}^{-1}$; 29 Mar. 2013: $\mathrm{N}$ at $22 \mathrm{~kg} \cdot \mathrm{ha}^{-1}, \mathrm{P}$ at 28 $\mathrm{kg} \cdot \mathrm{ha}^{-1}$, and $\mathrm{Fe}$ at $0.012 \mathrm{~kg} \cdot \mathrm{ha}^{-1} ; 2 \mathrm{Apr}$. 2014: $\mathrm{N}$ at $22 \mathrm{~kg} \cdot \mathrm{ha}^{-1}, \mathrm{P}$ at $28 \mathrm{~kg} \cdot \mathrm{ha}^{-1}$, and $\mathrm{Fe}$ at $0.012 \mathrm{~kg} \cdot \mathrm{ha}^{-1}$; 15 Apr. 2015: N at $22 \mathrm{~kg} \cdot \mathrm{ha}^{-1}, \mathrm{P}$ at $28 \mathrm{~kg} \cdot \mathrm{ha}^{-1}$, and $\mathrm{Fe}$ at $0.016 \mathrm{~kg} \cdot \mathrm{ha}^{-1}$. Nitrogen was applied as a urea-ammonium nitrate solution, P was applied as phosphoric acid, and $\mathrm{Fe}$ was applied as iron chelate.
During the first 2 years (2005 and 2006), weeds were controlled primarily with cultivation and hand rouging. Herbicides were screened for their effectiveness and plant tolerance in other trials (Shock et al., 2011). These products are not yet registered for commercial use on Lomatium species. Prowl ${ }^{\circledR}$ (pendimethalin; BASF, Research Triangle Park, NC) at $1.1 \mathrm{~kg} \cdot \mathrm{ha}^{-1}$ a.i. was broadcast on the soil surface for weed control on $17 \mathrm{Nov}$. 2006, 9 Nov. 2007, 15 Apr. 2008, 18 Mar. 2009, 4 Dec. 2009, 17 Nov. 2010, 9 Nov. 2011, 7 Nov. 2012, 26 Feb. 2014, and 13 Mar. 2015. Volunteer ${ }^{\circledR}$ (clethodim; Tenkoz, Inc., Alpharetta, GA) was broadcast at 0.07 $\mathrm{kg} \cdot \mathrm{ha}^{-1}$ a.i. on 18 Mar. 2009, 3 Apr. 2013, and $26 \mathrm{Feb}$. 2014. Hand rouging of weeds continued as necessary.

Seed yield was determined by a manual once-over harvest of all mature seed stalks in the middle $7.5 \mathrm{~m}$ of the two center rows of the four-row plots. On a few occasions, the 
Table 3. Regression analysis for Lomatium dissectum seed yield $\left(y, \mathrm{~kg} \cdot \mathrm{ha}^{-1}\right)$ in response to irrigation $(x, \mathrm{~mm} / \mathrm{season}) \mathrm{using}$ the equation $y=\mathrm{a}+\mathrm{b} \cdot x+\mathrm{c} \cdot x^{2}$ in $2009-$ 15 , and 7 -year average. For the quadratic equations, the amount of irrigation that resulted in maximum yield was calculated using the formula: $x=-\mathrm{b} / 2 \mathrm{c}$, where $\mathrm{b}$ is the linear parameter and $\mathrm{c}$ is the quadratic parameter.

\begin{tabular}{|c|c|c|c|c|c|c|c|}
\hline \multicolumn{8}{|c|}{ Water applied vs. yield } \\
\hline$\overline{\mathrm{Yr}}$ & Intercept & Linear & Quadratic & $R^{2}$ & $P$ & Highest yield $\left(\mathrm{kg} \cdot \mathrm{ha}^{-1}\right)$ & Water applied for highest yield ( $\mathrm{mm} /$ season) \\
\hline 2009 & 56.7 & 7.6 & -0.03 & 0.6 & 0.05 & 535 & 126 \\
\hline 2010 & 297.7 & 3.4 & -0.011 & 0.51 & 0.05 & 575 & 161 \\
\hline 2011 & 635.6 & 14.3 & -0.056 & 0.86 & 0.001 & 1,546 & 127 \\
\hline 2012 & 434.6 & 1.3 & -0.005 & 0.07 & NS & 521 & 132 \\
\hline 2013 & 591.1 & 6.1 & -0.013 & 0.68 & 0.01 & 1,329 & 242 \\
\hline 2014 & 443.8 & 5.7 & & 0.83 & 0.001 & 1,591 & 200 \\
\hline 2015 & 703.6 & 4.4 & & 0.78 & 0.01 & 1,583 & 200 \\
\hline Avg & & & & & & 1,097 & \\
\hline
\end{tabular}

Water applied plus spring precipitation vs. yield

\begin{tabular}{|c|c|c|c|c|c|c|c|}
\hline $\mathrm{Yr}$ & Intercept & Linear & Quadratic & $R^{2}$ & $P$ & Highest yield $\left(\mathrm{kg} \cdot \mathrm{ha}^{-1}\right)$ & $\begin{array}{c}\text { Water applied plus precipitation for } \\
\text { highest yield (mm/season) }\end{array}$ \\
\hline 2009 & $-1,032.6$ & 13.6 & -0.029 & 0.6 & 0.05 & 535 & 231 \\
\hline 2010 & -199.7 & 5.7 & -0.010 & 0.51 & 0.05 & 575 & 274 \\
\hline 2011 & $-1,870.0$ & 27.3 & -0.054 & 0.86 & 0.001 & 1,546 & 250 \\
\hline 2012 & 329.2 & 1.9 & -0.005 & 0.07 & NS & 521 & 200 \\
\hline 2013 & 455.8 & 6.5 & -0.012 & 0.68 & 0.01 & 1,329 & 267 \\
\hline 2014 & 195.7 & 5.6 & & 0.83 & 0.001 & 1,573 & 244 \\
\hline 2015 & 349.8 & 4.3 & & 0.78 & 0.01 & 1,569 & 282 \\
\hline \multicolumn{8}{|c|}{ Water applied plus spring precipitation vs. relative yield } \\
\hline
\end{tabular}

\begin{tabular}{|c|c|c|c|c|c|c|}
\hline $\mathrm{Yr}$ & Intercept & Linear & Quadratic & $R^{2}$ & $P$ & $\begin{array}{c}\text { Water applied plus precipitation } \\
\text { for highest relative yield ( } \mathrm{mm} / \text { season) }\end{array}$ \\
\hline 2009 & -200.4 & 2.6 & -0.0057 & 0.6 & 0.05 & 231 \\
\hline 2010 & -35.7 & 1.0 & -0.0018 & 0.51 & 0.05 & 274 \\
\hline 2011 & -124.3 & 1.8 & -0.0036 & 0.86 & 0.001 & 250 \\
\hline 2012 & 63.9 & 0.4 & -0.0009 & 0.07 & NS & 200 \\
\hline 2013 & 34.9 & 0.5 & -0.0009 & 0.68 & 0.01 & 267 \\
\hline 2014 & 12.7 & 0.4 & & 0.83 & 0.001 & 244 \\
\hline 2015 & 22.7 & 0.3 & & 0.78 & 0.01 & 282 \\
\hline Avg & -26.93 & 1.1 & -0.0022 & 0.94 & 0.001 & 243 \\
\hline
\end{tabular}

Table 4. Regression analysis for Lomatium grayi seed yield $\left(\mathrm{y}, \mathrm{kg} \cdot \mathrm{ha}^{-1}\right)$ in response to irrigation $(\mathrm{x}, \mathrm{mm} / \mathrm{season}) \mathrm{using}$ the equation $y=\mathrm{a}+\mathrm{b} \cdot x+\mathrm{c} \cdot x^{2}$ in $2007-15$, and 9 -year averages. For the quadratic equations, the amount of irrigation that resulted in maximum yield was calculated using the formula: $x=-\mathrm{b} / 2 \mathrm{c}$, where $\mathrm{b}$ is the linear parameter and $\mathrm{c}$ is the quadratic parameter.

\begin{tabular}{|c|c|c|c|c|c|c|}
\hline \multicolumn{7}{|c|}{ Water applied vs. yield } \\
\hline$\overline{\mathrm{Yr}}$ & Intercept & Linear & Quadratic & $R^{2}$ & $P$ & Highest yield $\left(\mathrm{kg} \cdot \mathrm{ha}^{-1}\right)$ \\
\hline 2007 & 42.0 & 0.5 & & 0.26 & 0.10 & 149 \\
\hline 2008 & 440.5 & 14.1 & -0.041 & 0.93 & 0.001 & 1,652 \\
\hline 2009 & 424.2 & 1.8 & & 0.38 & 0.05 & 790 \\
\hline 2010 & $1,160.0$ & 4.3 & -0.031 & 0.22 & NS & 1,309 \\
\hline 2011 & 638.7 & 1.3 & -0.013 & 0.10 & NS & 672 \\
\hline 2012 & 259.7 & 3.1 & -0.011 & 0.66 & 0.01 & 468 \\
\hline 2013 & 711.9 & 2.5 & & 0.25 & 0.10 & 1,204 \\
\hline 2014 & 597.0 & 15.9 & -0.059 & 0.64 & 0.05 & 1,654 \\
\hline 2015 & 208.7 & 8.1 & -0.037 & 0.71 & 0.01 & 649 \\
\hline Avg & & & & & & 950 \\
\hline \multicolumn{7}{|c|}{ Water applied plus fall, winter, and spring precipitation vs. yield } \\
\hline $\mathrm{Yr}$ & Intercept & Linear & Quadratic & $R^{2}$ & $P$ & Highest yield $\left(\mathrm{kg} \cdot \mathrm{ha}^{-1}\right)$ \\
\hline 2007 & -41.0 & 0.5 & & 0.26 & 0.10 & 148 \\
\hline 2008 & $-3,047.6$ & 27.4 & -0.040 & 0.93 & 0.001 & 1,652 \\
\hline 2009 & 20.0 & 1.8 & & 0.38 & 0.05 & 784 \\
\hline 2010 & $-2,723.2$ & 21.9 & -0.030 & 0.22 & NS & 1,309 \\
\hline 2011 & $-1,495.3$ & 10.3 & -0.01 & 0.10 & NS & 672 \\
\hline 2012 & -872.2 & 7.6 & -0.011 & 0.66 & 0.01 & 468 \\
\hline 2013 & 385.7 & 2.4 & & 0.25 & 0.10 & 1,197 \\
\hline 2014 & $-5,042.5$ & 39.3 & -0.058 & 0.64 & 0.05 & 1,654 \\
\hline 2015 & $-4,458.0$ & 27.2 & -0.036 & 0.71 & 0.01 & 649 \\
\hline \multicolumn{7}{|c|}{ Water applied plus fall, winter, and spring precipitation vs. relative yield } \\
\hline $\mathrm{Yr}$ & Intercept & Linear & Quadratic & $R^{2}$ & $P$ & $\begin{array}{l}\text { Water applied plus precipitation for } \\
\text { highest relative yield ( } \mathrm{mm} / \text { season) }\end{array}$ \\
\hline 2007 & -27.7 & 0.4 & & 0.26 & 0.10 & 357 \\
\hline 2008 & -188.3 & 1.7 & -0.0025 & 0.93 & 0.001 & 343 \\
\hline 2009 & 2.6 & 0.2 & & 0.38 & 0.05 & 425 \\
\hline 2010 & -212.6 & 1.7 & -0.0023 & 0.22 & NS & 369 \\
\hline 2011 & -233.1 & 1.6 & -0.00193 & 0.10 & NS & 419 \\
\hline 2012 & -192.6 & 1.7 & -0.0024 & 0.66 & 0.01 & 352 \\
\hline 2013 & 33.2 & 0.2 & & 0.25 & 0.10 & 335 \\
\hline 2014 & -317.5 & 2.5 & -0.0036 & 0.64 & 0.05 & 341 \\
\hline 2015 & -690.2 & 4.2 & -0.0056 & 0.71 & 0.01 & 375 \\
\hline Avg & -229.2 & 1.9 & -0.0026 & 0.59 & 0.05 & 358 \\
\hline
\end{tabular}


maturation and harvest of the nonirrigated plants preceded the harvest of the irrigated plants (Table 2). Seed was cleaned from stalks and chaff and was weighed. Seed yield means were compared by analysis of variance and linear and quadratic regression. Seed yield for each species each year was regressed separately against 1) applied water;
2) applied water plus spring precipitation; 3) applied water plus winter and spring precipitation; and 4) applied water plus fall, winter, and spring precipitation. Winter and

Table 5. Regression analysis for Lomatium triternatum seed yield $\left(y, \mathrm{~kg}_{\mathrm{h}} \cdot \mathrm{ha}^{-1}\right)$ in response to irrigation $(\mathrm{x}, \mathrm{mm} / \mathrm{season})$ using the equation $y=\mathrm{a}+\mathrm{b} \cdot x+\mathrm{c} \cdot x^{2}$ in $2007-$ 15 , and 9 -year average. For the quadratic equations, the amount of irrigation that resulted in maximum yield was calculated using the formula: $x=-\mathrm{b} / 2 \mathrm{c}$, where $\mathrm{b}$ is the linear parameter and $\mathrm{c}$ is the quadratic parameter.

\begin{tabular}{lrrrrrrr}
\hline & & \multicolumn{5}{c}{ Water applied vs. yield } \\
\hline Yr & Intercept & Linear & Quadratic & $R^{2}$ & $P$ & ${\text { Highest yield }\left(\mathrm{kg} \cdot \mathrm{ha}^{-1}\right)}^{\text {Water applied for highest yield (mm/season) }}$ \\
\hline 2007 & 3.7 & 0.1 & & 0.52 & 0.01 & 31 & 200 \\
2008 & 218.7 & 12.7 & -0.030 & 0.77 & 0.01 & 1,557 & 210 \\
2009 & 203.4 & 10.6 & -0.039 & 0.83 & 0.001 & 922 & 135 \\
2010 & $1,833.6$ & 18.0 & -0.046 & 0.83 & 0.001 & 3,580 & 194 \\
2011 & $2,220.9$ & 14.1 & -0.069 & 0.45 & 0.10 & 2,940 & 822 \\
2012 & 267.4 & 5.4 & -0.013 & 0.52 & 0.05 & 1,226 & 206 \\
2013 & 221.4 & 5.0 & & 0.68 & 0.01 & 1,705 & 200 \\
2014 & 282.0 & 7.1 & & 0.97 & 0.001 & 981 & 200 \\
2015 & 362.7 & 3.1 & & 0.51 & 0.01 & 1,529 & 200 \\
Avg & & & & & &
\end{tabular}

Water applied plus spring precipitation vs. yield

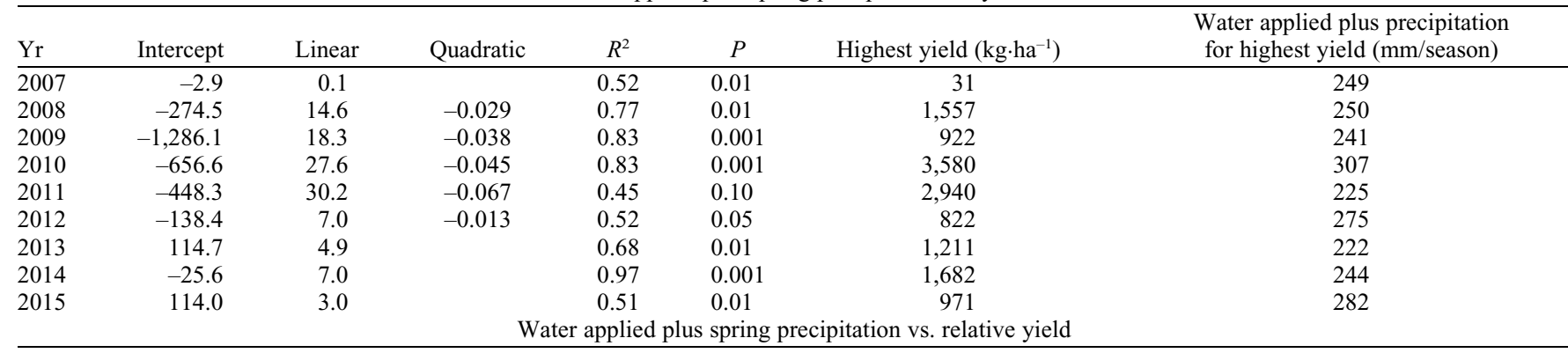

\begin{tabular}{lrrrrll}
\hline Yr & Intercept & Linear & Quadratic & \multicolumn{1}{c}{$R^{2}$} & $P$ & $\begin{array}{c}\text { Water applied plus precipitation } \\
\text { for highest relative yield (mm/season) }\end{array}$ \\
\hline 2007 & -9.8 & 0.5 & & 0.52 & 0.01 & 249 \\
2008 & -17.7 & 0.9 & -0.002 & 0.77 & 0.01 & 250 \\
2009 & -147.2 & 2.1 & -0.004 & 0.83 & 0.001 & 307 \\
2010 & -18.4 & 0.8 & -0.001 & 0.83 & 0.001 & 225 \\
2011 & -15.3 & 1.0 & -0.002 & 0.45 & 0.10 & 275 \\
2012 & -16.9 & 0.9 & -0.002 & 0.52 & 0.05 & 222 \\
2013 & 9.7 & 0.4 & & 0.68 & 0.01 & 244 \\
2014 & -1.5 & 0.4 & & 0.97 & 0.001 & 282 \\
2015 & 10.7 & 0.3 & & 0.51 & 0.01 & 265 \\
Avg & -3.8 & 0.8 & -0.001 & 0.85 & 0.001 & \\
\hline
\end{tabular}

Table 6. Regression analysis for Lomatium nudicaule and L. suksdorfii seed yield $\left(y, \mathrm{~kg}_{\mathrm{h}} \mathrm{ha}^{-1}\right)$ in response to irrigation $(x, \mathrm{~mm} / \mathrm{season}) \mathrm{using}$ the equation $y=\mathrm{a}+\mathrm{b} \cdot x+$ c. $x^{2}$ in $2012-15$. For the quadratic equations, the amount of irrigation that resulted in maximum yield was calculated using the formula: $x=-b / 2 c$, where $b$ is the linear parameter and $\mathrm{c}$ is the quadratic parameter. Lomatium nudicaule failed to respond to irrigation.

\begin{tabular}{|c|c|c|c|c|c|c|c|}
\hline \multicolumn{8}{|c|}{ Water applied vs. yield } \\
\hline Yr & Intercept & Linear & Quadratic & $R^{2}$ & $P$ & Highest yield $\left(\mathrm{kg} \cdot \mathrm{ha}^{-1}\right)$ & $\begin{array}{c}\text { Water applied for } \\
\text { highest yield ( } \mathrm{mm} / \text { season) }\end{array}$ \\
\hline \multicolumn{8}{|c|}{ L. nudicaule } \\
\hline 2014 & 789.0 & -0.6 & & 0.08 & NS & 789 & 0 \\
\hline 2015 & 482.3 & 0.1 & -0.0041 & 0.17 & NS & 483 & 16 \\
\hline Avg & & & & & & 505 & \\
\hline 2015 & 844.4 & 5.6 & & 0.43 & 0.05 & 1,967 & 200 \\
\hline Avg & & & & & & 1,086 & \\
\hline
\end{tabular}

Table 7. Average seed yields for five Lomatium species over multiple years.

\begin{tabular}{|c|c|c|c|c|}
\hline \multirow[b]{2}{*}{ Species } & \multicolumn{3}{|c|}{ Avg seed yield by irrigation treatment $\left(\mathrm{kg} \cdot \mathrm{ha}^{-1}\right)$} & \multirow[b]{2}{*}{$\operatorname{LSD}_{(0.05)}$} \\
\hline & No irrigation & $100 \mathrm{~mm} / \mathrm{season}$ & $200 \mathrm{~mm} / \mathrm{season}$ & \\
\hline Lomatium triternatum & 703 & 1,384 & 1,455 & 188 \\
\hline Lomatium suksdorfii & 359 & 309 & 318 & NS \\
\hline
\end{tabular}


spring precipitation occurred in the same year that yield was determined; fall precipitation occurred the prior year.

Seed yield $\left(y, \mathrm{~kg} \cdot \mathrm{ha}^{-1}\right)$ in response to irrigation or irrigation plus precipitation $(x$, $\mathrm{mm}$ /season) was estimated by the equation $y=\mathrm{a}+\mathrm{b} \cdot x+\mathrm{c} \cdot x^{2}$. For the quadratic equations, the amount of irrigation $\left(x^{\prime}\right)$ that resulted in maximum yield $\left(y^{\prime}\right)$ was calculated using the formula $x^{\prime}=-\mathrm{b} / 2 \mathrm{c}$, where $\mathrm{a}$ is the intercept, $\mathrm{b}$ is the linear parameter, and $\mathrm{c}$ is the quadratic parameter. For the linear regressions, the highest seed yield for a species in a given year was based was on the highest measured average seed yield.

Adding the seasonal precipitation to the irrigation response equation would have the potential to provide a closer estimate of the amount of water required for maximum seed yields for each species. Regressions of seed yield for each species each year were calculated on all the sequential seasonal amounts of precipitation and irrigation, but only some of the regressions are reported below. For each species, the period of precipitation plus applied water that had the lowest standard deviation for irrigation plus precipitation over the years was chosen as the most reliable independent variable for predicting seed yield. To compare yield responses over years, regressions were also made on the relative seed yields compared with irrigation plus precipitation. Relative seed yield for each plot was calculated as the percentage of the yield of the highest yielding treatment for each species for each year.

\section{Results}

Lomatium dissectum began flowering and producing seed in 2009, the 4th year after fall planting in 2005 (Tables 2 and 3). Flowering and seed production began for $L$. grayi and $L$. triternatum in the 2 nd year (2007), L. nudicaule in the 3rd year (2012), and L. suksdorfii in the 4th year (2013) after fall planting (Tables 2 and 4-6). Although there were tremendous variations in seed yields over species and years, general tendencies emerged for the mean seed yields for each species and irrigation treatments (Table 7).

Lomatium dissectum, fernleaf biscuitroot. Seed yields of $L$. dissectum exhibited a quadratic response to irrigation amount in 200913 (Table 3; Figs. 1-3). The quadratic response to irrigation in 2012 was not statistically significant. Seed yield of $L$. dissectum exhibited linear responses to irrigation rate in 2014 and 2015. The amount of water applied for maximum seed yield, calculated from the regression equations, ranged from 126 to $242 \mathrm{~mm}$ per season. Seed yields were estimated to be highest with 200 to $282 \mathrm{~mm}$ of total applied water plus spring precipitation. The highest yields averaged $1097 \mathrm{~kg} \cdot \mathrm{ha}^{-1}$ and ranged from 521 to $1573 \mathrm{~kg} \cdot \mathrm{ha}^{-1}$. Averaged over 7 years, relative seed yield was highest with $243 \mathrm{~mm}$ of applied water plus spring precipitation (Fig. 3).

Lomatium grayi, Gray's biscuitroot. Seed yields of L. grayi exhibited quadratic responses

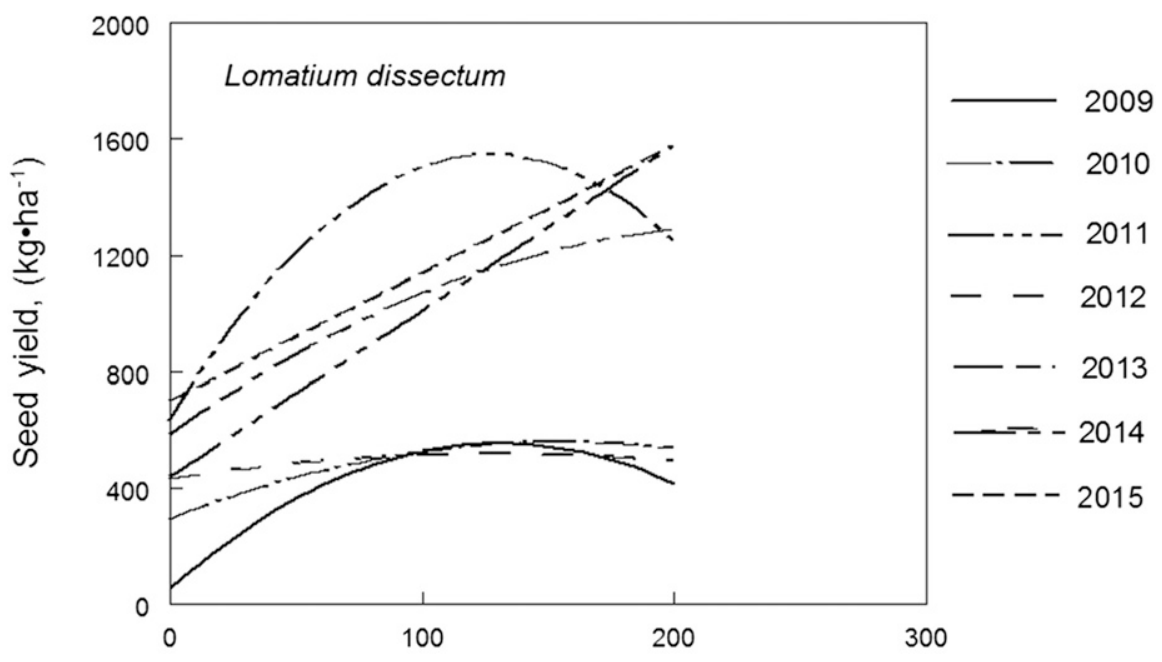

Water applied, (mm)

Fig. 1. Seed yield response of Lomatium dissectum to water applied in 2009-15.

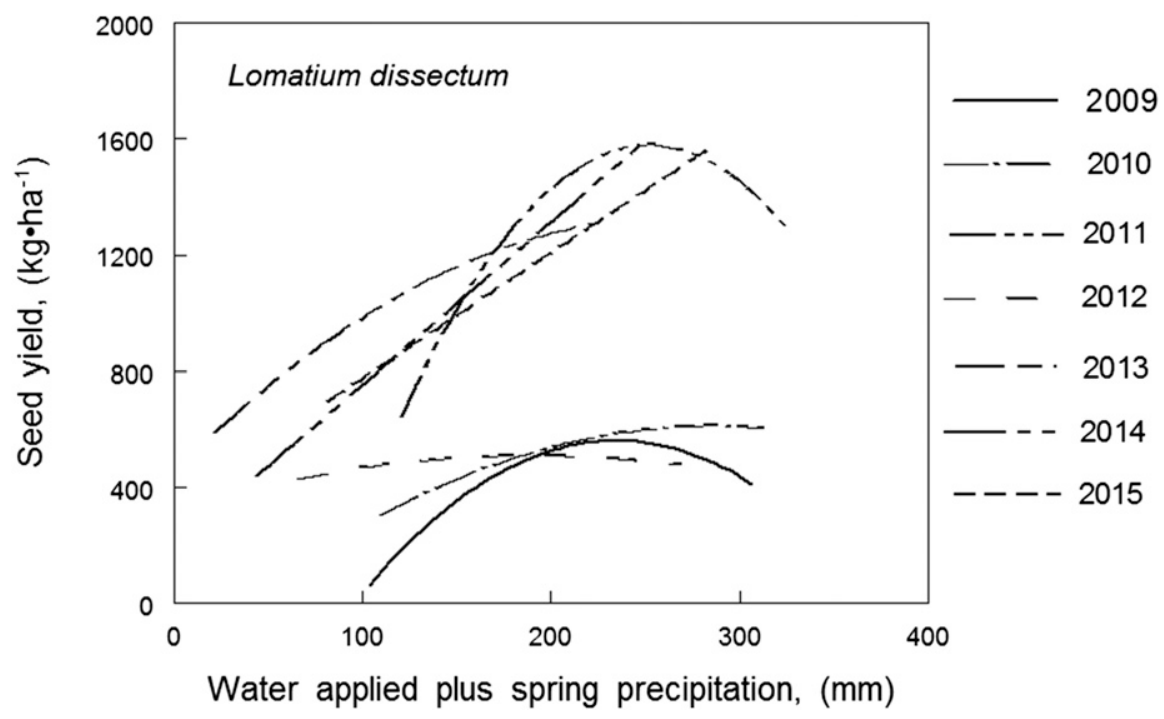

Fig. 2. Seed yield response of Lomatium dissectum to water applied plus spring precipitation in 2009-15.

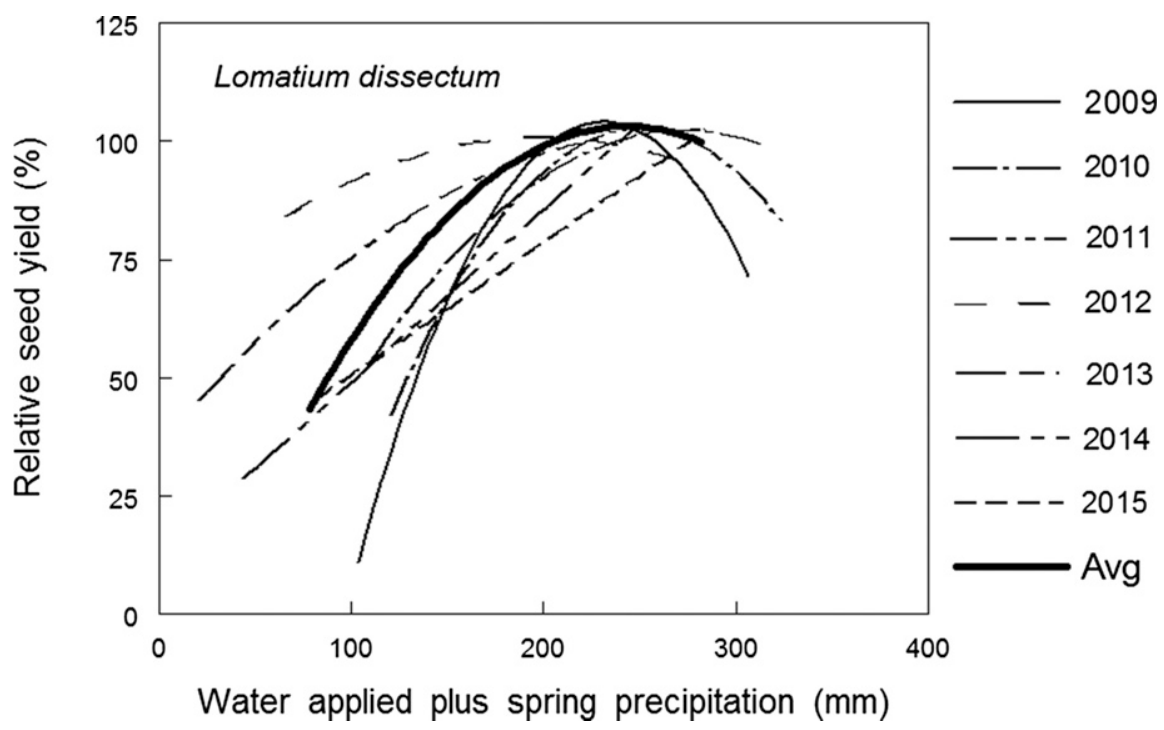

Fig. 3. Relative seed yield response of Lomatium dissectum to water applied plus spring precipitation in 2009-15 and the 7-year average relative seed yield response. 
to irrigation rate in $2008,2010,2011,2012$, 2014, and 2015; linear responses in 2007, 2009, and 2013; and no statistically significant responses in 2010 and 2011 (Table 4; Figs. 4-6). The amount of water applied for the highest yield, calculated from the regression equations, ranged from 51 to $200 \mathrm{~mm}$ per season. Seed yields of $L$. grayi were estimated to be highest with 335 to $425 \mathrm{~mm}$ of total applied water plus fall, winter, and spring precipitation, depending on the year. These results imply that if a year were very dry, more than $200 \mathrm{~mm}$ of irrigation would be required to maximize seed yields. The highest yields averaged $950 \mathrm{~kg} \cdot \mathrm{ha}^{-1}$ and ranged from 148 to $1654 \mathrm{~kg} \cdot \mathrm{ha}^{-1}$, depending on the year. Averaged over 9 years, relative seed yield was highest with $358 \mathrm{~mm}$ of total applied water plus fall, winter, and spring precipitation.

Lomatium triternatum, nineleaf biscuitroot. Seed yields of $L$. triternatum exhibited quadratic responses to irrigation rate in 2008-12 (Table 5; Figs. 7-9). Seed yields in 2007, 2013, 2014, and 2015 showed linear responses to irrigation. Seed yields were estimated to be highest using 102 to $210 \mathrm{~mm}$ of applied water depending on the year. Seed yields were estimated to be highest using 222 to $307 \mathrm{~mm}$ of applied water plus spring precipitation and ranged from 31 to $3580 \mathrm{~kg} \cdot \mathrm{ha}^{-1}$, depending on the year and averaged $1529 \mathrm{~kg} \cdot \mathrm{ha}^{-1}$. Averaged over 9 years, relative seed yield was highest with $265 \mathrm{~mm}$ of total applied water plus spring precipitation.

Lomatium nudicaule, barestem biscuitroot. Over 4 years of production, seed yields of $L$. nudicaule showed no significant response to water applied (Table 6). Maximum yields averaged $505 \mathrm{~kg} \cdot \mathrm{ha}^{-1}$ and ranged from 139 to $789 \mathrm{~kg} \cdot \mathrm{ha}^{-1}$, depending on the year.

Lomatium suksdorfii, Suksdorf's desertparsley. Seed yields of $L$. suksdorfii did not respond significantly to water applied in 2014, the first year of seed production (Table 6). Seed yields in 2015 showed a linear response to irrigation. Seed yields were estimated to be maximized by $282 \mathrm{~mm}$ of total applied water plus spring precipitation in 2015. Maximum yields averaged $1086 \mathrm{~kg} \cdot \mathrm{ha}^{-1}$ and were $205 \mathrm{~kg} \cdot \mathrm{ha}^{-1}$ in 2014 and $1950 \mathrm{~kg} \cdot \mathrm{ha}^{-1}$ in 2015. The higher seed yield in 2015 may be related to advanced plant maturity and greater stature than in 2014.

\section{Discussion}

Seasonal precipitation varied greatly among years, as did the amount of water required for maximum seed production. Adding seasonal precipitation to applied water reduced variation in the optimal water requirement for maximum seed production (Table 8). The regression analyses showed high variability in the optimum amount of water for maximum seed yield among years. When precipitation was added to the amount of water applied in the regressions, the variability in the optimum amount of water decreased.

On average, $L$. dissectum started flowering on about 9 Apr., and L. triternatum started flowering around 18 Apr. (Table 2). For these

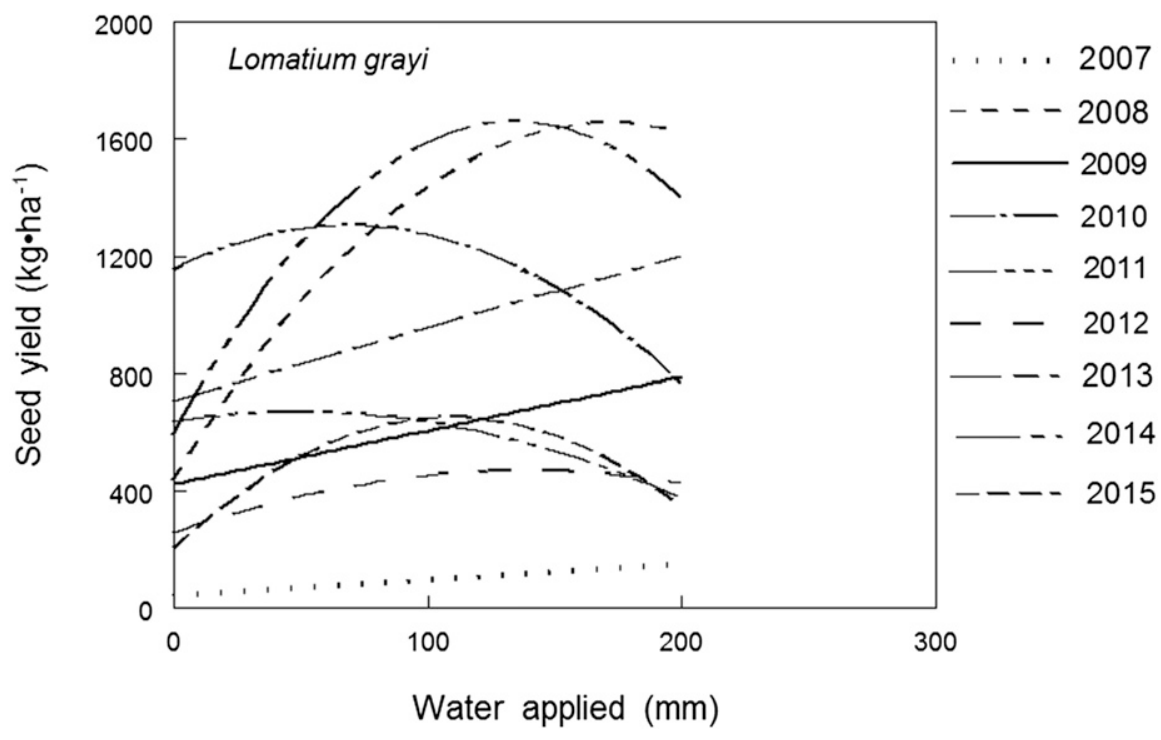

Fig. 4. Seed yield response of Lomatium grayi to water applied in 2007-15.

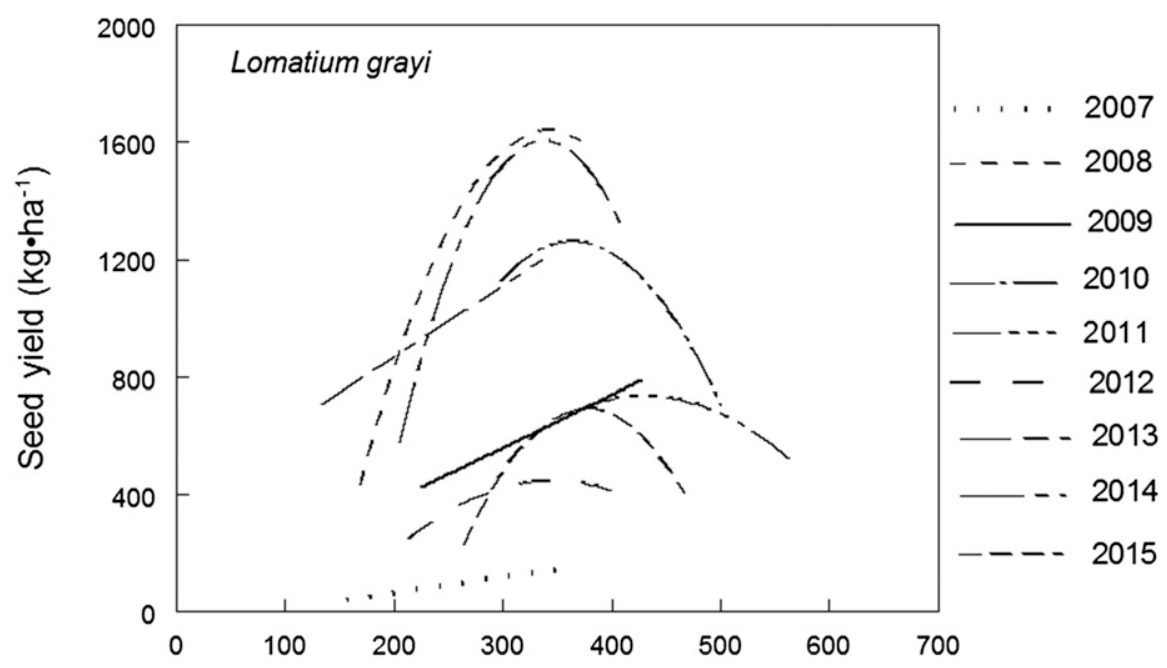

Water applied plus fall, winter, and spring precipitation (mm)

Fig. 5. Seed yield response of Lomatium grayi to water applied plus fall, winter, and spring precipitation in 2007-15.

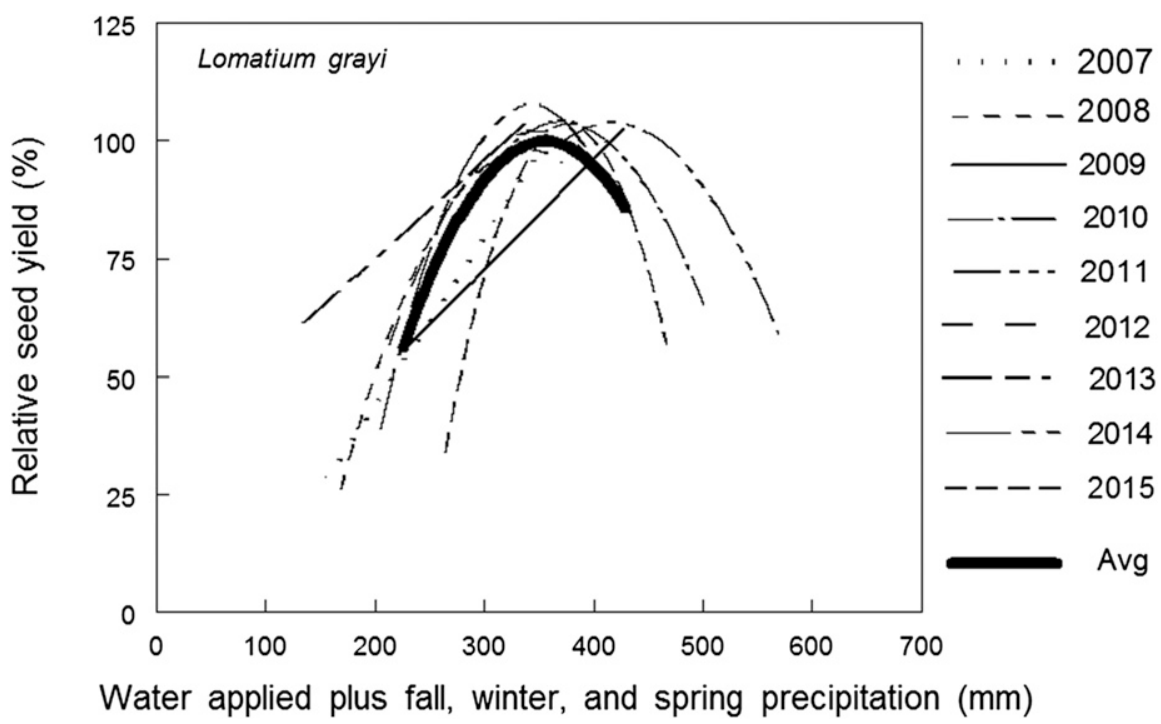

Fig. 6. Relative seed yield response of Lomatium grayi to water applied plus fall, winter, and spring precipitation in 2007-15 and the 9-year average relative seed yield response. 


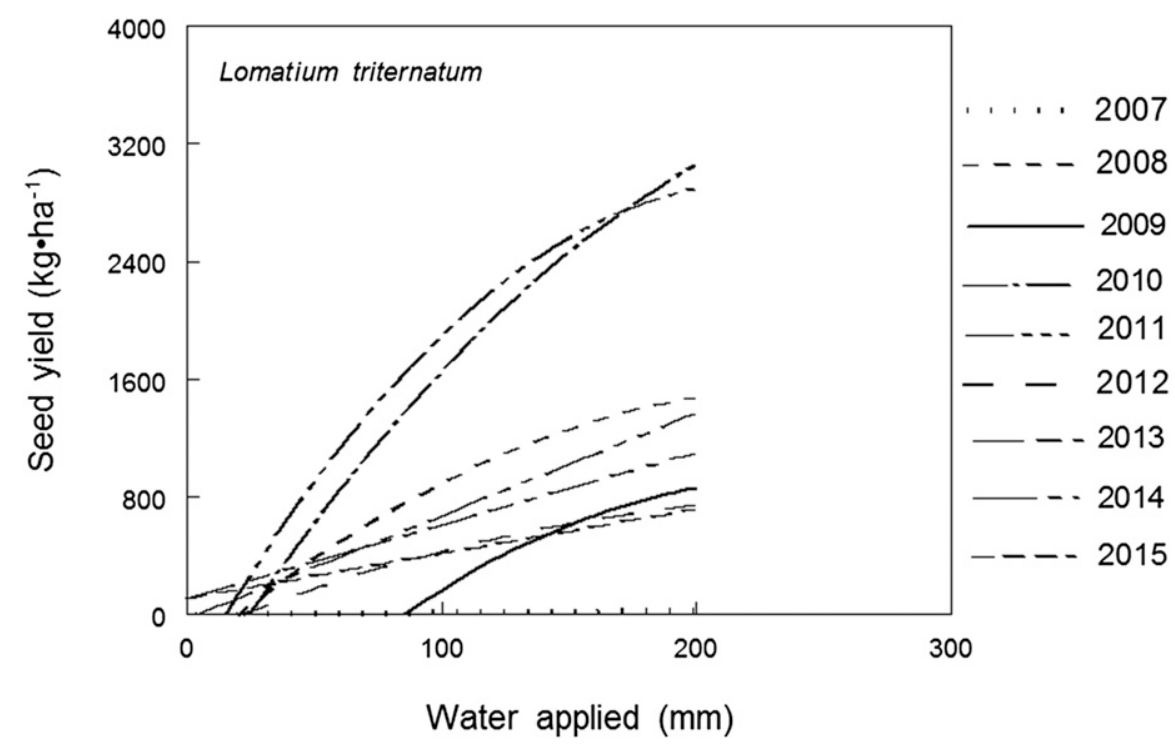

Fig. 7. Seed yield response of Lomatium triternatum to water applied in 2007-15.

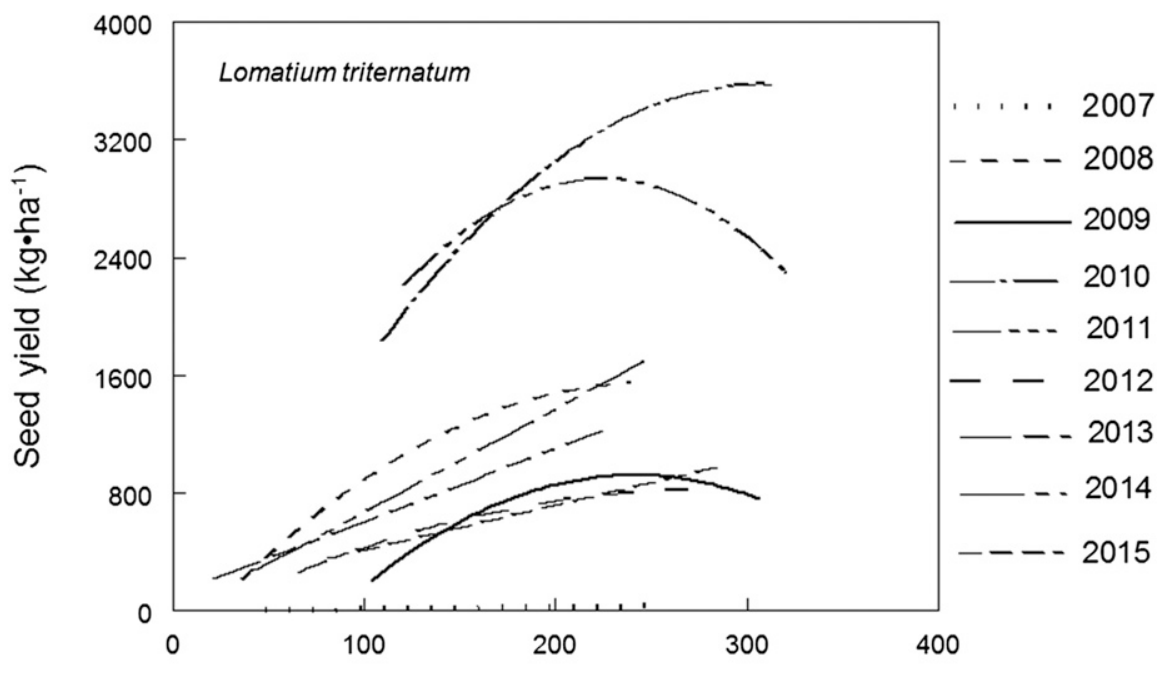

Water applied plus spring precipitation $(\mathrm{mm})$

Fig. 8. Seed yield response of Lomatium triternatum to water applied plus spring precipitation in 2007-15.

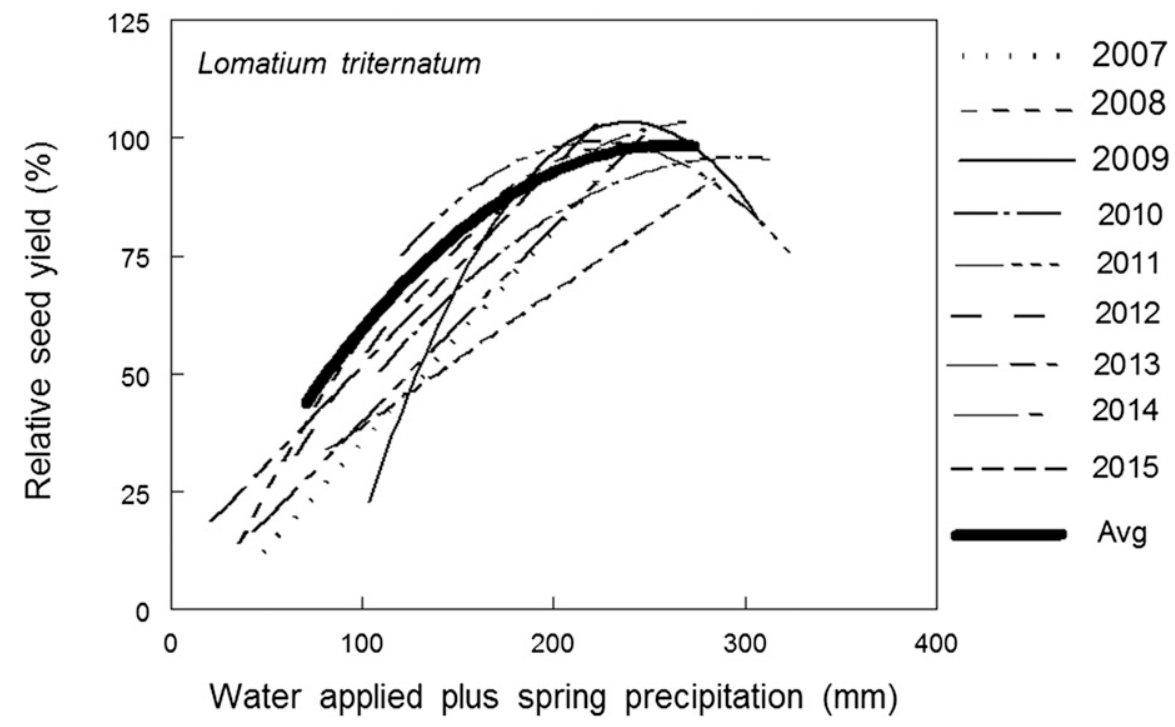

Fig. 9. Relative seed yield response of Lomatium triternatum to water applied plus spring precipitation in 2007-15 and the 9-year average relative seed yield response. two species, the addition of spring precipitation to applied irrigation water resulted in the lowest standard deviation of the amount of water applied for maximum yield according to the quadratic equations for 2007-15 (Table 9). For L. grayi, the addition of fall, winter, and spring precipitation to applied irrigation water resulted in the lowest standard deviation of the amount of water applied for maximum yield according to the regression equations for 2007-15 (Table 9; Figs. 46). Lomatium grayi usually started flowering in early to mid-March (Table 2), possibly explaining why it might have responded more to fall, winter, and spring precipitation than $L$. dissectum and L. triternatum.

Other studies that examined responses of xerophytic plants to irrigation found similar responses within the ranges of irrigation in our study. In Tucson, AZ, with annual precipitation of $293 \mathrm{~mm}$, native grass and native woody plant establishment from seed was optimum with 187 to $210 \mathrm{~mm}$ of irrigation plus precipitation (Roundy et al., 2001). In the Chihuahuan Desert in New Mexico, with annual precipitation of $211 \mathrm{~mm}$, only 6 of 15 species increased vegetative growth in response to $338 \mathrm{~mm}$ of annual irrigation (Gutierrez and Whitford, 1987).

There are few published studies examining seed production of native plants in response to irrigation in arid regions. In a westcentral Texas, area that receives $530 \mathrm{~mm}$ of annual precipitation, Petersen and Ueckert (2005) found that seed production of Atriplex canescens (fourwing saltbush) did not respond to either $400 \mathrm{~mm}$ of irrigation in one year or $200 \mathrm{~mm}$ of irrigation the next year. In the Owens Valley, CA, with annual precipitation of $113 \mathrm{~mm}$, Sarcobatus vermiculatus (greasewood) seed yields were significantly higher when irrigated (Breen and Richards, 2008). These studies were not designed to determine optimum amounts of irrigation for seed yield.

In this study, all Lomatium species tested, except $L$. nudicaule, responded to irrigation with increased seed yields. For the three species tested for 7-9 years ( $L$. dissectum, L. grayi, and L. triternatum), seed yields were increased significantly by irrigation. Seed yields of L. suksdorfii also increased by irrigation in 2015. The amount of irrigation and precipitation needed for maximum Lomatium seed yields in this study $(200-400 \mathrm{~mm} /$ year) was substantially lower than irrigation plus precipitation requirements for row crops in the Treasure Valley of Oregon (500 $800 \mathrm{~mm} /$ year, AgriMet, 2016). Although Lomatium species are perennials, they complete their cycle from sprouting to seed harvest by mid-June, thus their irrigation requirements would be expected to be lower. However, irrigation requirements for Lomatium are low even when compared with an early season crop such as winter wheat (Triticum aestivum), which has an average water requirement of $633 \mathrm{~mm}$ in the Treasure Valley.

Studies of cultural practices for native plants are critical to increasing seed production and availability of plant material used in 
Table 8. Precipitation and growing degree-days at the Malheur Experiment Station, Ontario, OR, 2006-15. Fall: 22 Sept. to $21 \mathrm{Dec}$.; winter: 22 Dec. to 21 Mar.; and spring: 22 Mar. to 21 June.

\begin{tabular}{lccccc}
\hline & \multicolumn{3}{c}{ Precipitation $(\mathrm{mm})$} & & Growing degree-days $\left(10-30^{\circ} \mathrm{C}\right)$ \\
\cline { 2 - 4 } & Spring & Spring + winter & Spring + winter + fall & & January-June \\
\hline 2006 & 86 & 256 & 97 & 157 & 707 \\
2008 & 49 & 81 & 169 & 781 \\
2009 & 103 & 170 & 225 & 604 \\
2010 & 110 & 214 & 298 & 671 \\
2011 & 121 & 235 & 367 & 539 \\
2012 & 66 & 156 & 213 & 476 \\
2013 & 22 & 60 & 135 & 682 \\
2014 & 44 & 130 & 205 & 733 \\
2015 & 82 & 151 & 265 & 741 \\
& 67 & $71-y e a r$ avg & & 895 \\
& & 147 & 230 & $22-y e a r$ avg \\
\hline
\end{tabular}

Table 9. Standard deviations of amount of water applied for maximum seed yield for three Lomatium species.

\begin{tabular}{|c|c|c|c|c|c|}
\hline \multirow[b]{2}{*}{ Species } & \multirow[b]{2}{*}{ Years } & \multicolumn{4}{|c|}{$\begin{array}{l}\text { Standard deviation of amount of water } \\
\text { applied for the highest seed yield (mm) }\end{array}$} \\
\hline & & $\begin{array}{c}\text { Water } \\
\text { applied }\end{array}$ & $\begin{array}{c}\text { Water applied } \\
\text { plus spring } \\
\text { precipitation }\end{array}$ & $\begin{array}{l}\text { Water applied } \\
\text { plus winter } \\
\text { and spring } \\
\text { precipitation }\end{array}$ & $\begin{array}{c}\text { Water applied } \\
\text { plus fall, } \\
\text { winter, and spring } \\
\text { precipitation }\end{array}$ \\
\hline Lomatium dissectum & $2009-15$ & 47.2 & 29.4 & 35.8 & 61.9 \\
\hline Lomatium grayi & $2007-15$ & 56.6 & 42.9 & 47.9 & 34.0 \\
\hline Lomatium triternatum & $2007-15$ & 38.9 & 28.9 & 43.8 & 58.4 \\
\hline
\end{tabular}

restoration of ecosystems in the Intermountain West. As restoration needs increase, the economic opportunities for native plant seed growers will also increase. Developing in-depth knowledge on seed production practices will support the native seed industry in the future.

\section{Conclusions}

The seed yields of four of the five Lomatium species (L. dissectum, L grayi, L. triternatum, and L. suksdorfii) responded significantly to subsurface drip irrigation. The irrigation requirements for seed production of $L$. dissectum and L. triternatum were best estimated by a quadratic response to irrigation plus spring precipitation. The irrigation requirements for seed production of $L$. grayi were best estimated by a quadratic response to irrigation plus precipitation during the fall, winter, and spring. Additional trials are needed for $L$. suksdorfii to better define its seed yield response to precipitation plus applied water.

\section{Literature Cited}

AgriMet. 2016. Bureau of Reclamation Pacific Northwest Region. 21 Mar. 2016. <http://www. usbr.gov/pn/agrimet/>.

Balch, J.K., B.A. Bradley, C.M. D'Antonio, and J. Gómez-Dans. 2013. Introduced annual grass increases regional fire activity across the arid
Agr. Natural Resources Conservation Serv., Boise, ID.

Parkinson, H., C. Zabinski, and N. Shaw. 2013. Impact of native grasses and cheatgrass (Bromus tectorum) on Great Basin forb seedling growth. Rangeland Ecol. Mgt. 66:174180.

Petersen, J.L. and D.J. Ueckert. 2005. Fourwing saltbush seed yield and quality: Irrigation, fertilization, and ecotype effects. Rangeland Ecol. Mgt. 58:299-307.

Robichaud, P.R., J.L. Beyers, and D.G. Neary. 2000. Evaluating the effectiveness of postfire rehabilitation treatments. Gen. Tech. Rep. RMRS-GTR-63. U.S. Dept. Agr., Forest Serv., Fort Collins, CO.

Roundy, B.A., H. Heydari, C.W.S.E. Smith, and B.M.M. Pater. 2001. Summer establishment of Sonoran Desert species for revegetation of abandoned farmland using line source sprinkler irrigation. Arid Land Res. Mgt. 15: 23-39.

Shaw, N.L. and S. Jensen. 2014. The challenge of using native plant materials for sagebrush steppe restoration in the Great Basin, USA, p. 141-159. In: K. Kiehl, A. Kirmer, N.L. Shaw, and S. Tischew (eds.). Guidelines for native seed production and grassland restoration. Cambridge Scholars, Newcastle upon Tyne, UK.

Shock, C.C., E.B.G. Feibert, L.D. Saunders, C.A. Parris, and N.L. Shaw. 2011. Evaluation of herbicides for weed control in forb seed production, p. 186-198. In: C.C. Shock (ed.). Oregon State University Agricultural Experiment Station, Malheur Experiment Station Annual Report 2010, Department of Crop and Soil Science Ext/CrS 132. <http://cropinfo.net/AnnualReports/ 2010/24-EvaluationHerbicidesForbs.php>.

Shock, C.C., E.B.G. Feibert, N.L. Shaw, M.P Shock, and L.D. Saunders. 2015. Irrigation to enhance native seed production for Great Basin restoration. Nat. Areas J. 35(1):74-82.

Shock, M.P., C.C. Shock, E.B.G. Feibert, C.A. Parris, L.D. Saunders, R.K. Sampangi, N.L. Shaw, and T.K. Welch. 2012a. Fernleaf biscuitroot: Lomatium dissectum (LODI). Ext/CrS 138. Sustainable Agriculture Techniques. Oregon State University, Dept. Crop and Soil Sci., Corvallis, OR.

Shock, M.P., C.C. Shock, E.B.G. Feibert, N.L. Shaw, L.D. Saunders, and R.K. Sampangi. 2012b. Cultivation and irrigation of fernleaf biscuitroot (Lomatium dissectum) for seed production. HortScience 47:1525-1528.

Tilley, D., L. St. John, D. Ogle, and N.L. Shaw. 2010a. Plant guide for nineleaf biscuitroot (Lomatium triternatum). U.S. Dept. Agr. Natural Resources Conservation Serv., Aberdeen Plant Materials Center, Aberdeen, ID.

Tilley, D., L. St. John, D. Ogle, N.L. Shaw, and J. Cane. 2010b. Plant guide for fernleaf biscuitroot (Lomatium dissectum). U.S. Dept. Agr. Natural Resources Conservation Serv., Aberdeen Plant Materials Center, Aberdeen, ID.

Thompson, J.N. 1998. Coping with multiple enemies: 10 years of attacks on Lomatium dissectum plants. Ecology 79:2550-2554. 